\title{
AN EXPLORER OF LEGAL BORDERLANDS: A REVIEW OF WILLIAM TWINING'S JURIST IN CONTEXT, A MEMOIR $^{1}$
}

\author{
PEDRO RUBIM BORgES FORTES ${ }^{2}$
}

\section{INTRODUCTION}

This essay reviews the recent autobiography written by Professor William Twining and published at the Law in Context Series at Cambridge University Press. This book is excellent and indispensable reading for everyone interested in jurisprudence, globalization of law, and interdisciplinary legal studies. Twining wrote a comprehensive memoir of his life and work, providing a series of inspirational stories, anecdotes, and reflections about his adventurous life. His autobiography offers a window into the borderlands of law in contemporary society, as Twining has been at the forefront of interdisciplinary legal studies, embracing legal realism, transforming legal education, and promoting the law in context perspective through his teachings, writings, and editorial work. The experience of being a biographer of the great

\footnotetext{
1 This short review essay is one of my last published works as a member of the Oxford Centre for SocioLegal Studies (CSLS) and it resulted from knowledge developed there, initially as a DPhil between 2012 and 2017 and subsequently as a Research Associate in the academic years of 2017/2018 and 2018/2019. I am grateful to everyone who supported me in all those years at CSLS and the University of Oxford, especially Fernanda Pirie, Marina Kurkchiyan, Sue Bright, Linda Mulcahy, Mavis Maclean, Timothy Endicott, John Gardner, Stefan Vogenauer, Paul Yowell, Leigh Payne, Chris Hodges, Chris Decker, Stephen Weatherill, Naomi Creutzfeldt, Agnieszka Kubal, Bettina Lange, Momberg Uribe, Denis Galligan and, last but not least, William Twining. I am grateful to the Editor-Chief and Dean of the National Law School at the Federal University of Rio de Janeiro, Professor Carlos Bolonha, for the opportunity to write this book review. Professor Nelson Rosenvald recommended reading the book Scholars of Tort Law and his suggestion was especially helpful for the passage related to Patrick Atiyah in this book review. Executive-Editor Daniel Lucas did a terrific job in editing the entire number and I am grateful that he used in the cover a photograph that I took as part of my farewell to Oxford. Errors are all mine.

2 DPHIL (Oxford), JSM (Stanford), LLM (Harvard), MBE (Coppe-UFRJ), BA (PUC-Rio), LLB (UFRJ). Contato: pfortes@alumni.stanford.edu.
} 
American legal realist Karl Llewellyn ${ }^{3}$ possibly influenced Twining in collecting the relevant episodes of his own existence to prepare the writing of this excellent book. ${ }^{4}$

Professor Nicola Lacey, a legal theorist herself and biographer of H.L.A. Hart, wrote the first lines of the book in her foreword: "For over sixty years, William Twining has been at the centre of legal education and legal scholarship in the English speaking world". ${ }^{5}$ It is true that Twining has been a central intellectual figure of legal academia, but the idea of center may imply core and status quo. However, the analysis of Twining's life and work reveals a jurist who departed from the dominant doctrinal and positivistic tradition of law and explored the borderlands of the discipline. Even if he was fascinated intellectually and converted by the series of lectures that H.L.A. Hart delivered at Oxford in 1954, ${ }^{6}$ Twining would later suffer a culture shock by learning that his favorite doctrinal book - Salmond on Torts - was useless for the professional experience of lawyers specialized in injuries cases, who settled out of court with the insurance company. ${ }^{7}$ Likewise, Twining also moved away from his colonial childhood as the son of a colonial administrator in Uganda and Mauritius and eventually developed a post-colonial attitude as a middle-aged scholar. ${ }^{8}$ Moreover, Twining was responsible for broadening the scope of law and enlarging the discipline through the development of the Law and Context Series, whose "aim was 'to subvert and revolutionise' (sic) the prevailing orthodoxy in English legal education". ${ }^{9}$ Therefore, Twining has been a central figure in legal academia, but not by positioning himself at the center, but rather by exploring the legal borderlands of jurisprudence, globalization of law, and interdisciplinary legal studies.

Therefore, this review essay will examine these facets of Twining's life and work, combining his autobiography with his academic production. Additionally to this introduction, section two will present his personal view of jurisprudence. Section three will discuss Twining's contributions to the study of globalization of law in connection with his experience in Khartoum, Dar es Salaam, Belfast, Warwick, and UCL. Section four will focus on interdisciplinary legal studies. Section five will bring concluding remarks.

\footnotetext{
${ }^{3}$ William Twining, Karl Llewellyn and the Realist Movement (CUP 2nd edn 2012).

${ }^{4}$ In one of my recent meetings with him in Oxford, he suggested that I should keep notes, records, and materials related to my life and professional experience in case I ever decide to write a biographical book myself.

${ }^{5}$ Nicola Lacey, Foreword, in William Twining, Jurist in Context: A Memoir, Cambridge: CUP (2019), page xi

${ }^{6}$ William Twining, Jurist in Context: A Memoir (CUP 2019) 18-19.

7 Idem 23-24.

8 Idem 7-9.

${ }^{9}$ Idem 91.
} 


\section{TWINING'S STANDPOINT AND HIS PERSONAL VIEW OF JURISPRUDENCE}

In his Great Juristic Bazaar, William Twining already provided some of the key ideas related to his personal view of jurisprudence - a synonym of legal theory and larger than legal philosophy, which is just one of its parts..$^{10}$ In his view, jurisprudence can be identified as a heritage, an ideology, and the activity of theorizing. ${ }^{11}$ Importantly, he reflected about the jurisprudence jobs as a series of functions like mapping views, elucidating concepts, developing theories and/or hypotheses, and critically examining assumptions. ${ }^{12}$ Likewise, an intellectual history could also be deemed as a jurisprudential contribution to the health of the discipline of law. ${ }^{13}$ In the introduction to the Great Juristic Bazaar, William Twining presented himself as a loyal disciple of Karl Llewellyn in considering jurisprudence as "an exercise in self-definition" and a foundational layer for critical self-awareness - and eventually the development of a Weltanschauung or a view of the world..$^{14}$ In his autobiographical book, he finally provides the full comprehensive examination of his view of the jurisprudential world as part of an intellectual history in which he has been one of the most prolific, inspirational, and innovative actors. As he clearly pronounced in the beginning of his memoir, the "book is based on a particular vision of Jurisprudence, which many do not share." 15

His main point is that, as he nicely puts it, "jurisprudence is not a one-question subject".$^{16}$ Many view the discipline as monothematic and debate only the concept of law. ${ }^{17}$ In contrast, Twining developed his conceptions of law beyond the design of a municipal legal system and developed important reflections on interdisciplinary legal studies, legal realism and globalization of law. ${ }^{18}$ In his own formulation of a working conception of law, "from a global perspective it is illuminating to conceive of law as a species of institutionalized social practice that is oriented to ordering relations between subjects at one or more levels of relations and of ordering". ${ }^{19}$ This formulation facilitates

${ }^{10}$ William Twining, Great Juristic Bazaar: Jurists Texts and Lawyer's Stories (Ashgate 2002), 3.

${ }^{11} \mathrm{Idem}$.

${ }^{12}$ Idem.

${ }^{13} \mathrm{Idem}$.

${ }^{14}$ Idem, 4.

${ }_{15}$ William Twining, Jurist in Context: A Memoir (CUP 2019) 1.

${ }^{16}$ Idem 4.

${ }^{17}$ See H.L.A. Hart, The Concept of Law (OUP ).

${ }^{18}$ William Twining, General Jurisprudence: Understanding Law from a Global Prespective (CUP 2009) Ch. 4.

${ }^{19}$ Idem, 117.

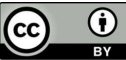


the analyses of various forms of non-state law - that would fail the test of the rule of recognition designed by positivists and the standards of normative integrity set by interpretivists -, encouraging the exploration of the borderlands of law in society. Criticizing Hart, Rawls, Dworkin, Kelsen, and Raz for their narrow view of law, Twining argues for a broad conception of law that focuses on "all levels of relations and of ordering, relations between these levels, and all important forms of law including supra-state (e.g. international, regional) and non-state law (e.g. religious law, transnational law, chthonic law i.e. tradition/custom) and various forms of 'soft law'" 20 . Not surprisingly, he considers that the canon of jurisprudence should be expanded, reviewed, and reinterpreted..$^{21}$

In his memoir, Twining explains that clarification of standpoint is a useful starting point for jurisprudential enquiry and the meaning of law depends on "who is asking the question in what context for what reason". ${ }^{22}$ His epiphany on the relevance of standpoint came when he read Colingwood's Autobiography in $1955^{23}$ and realized that "one needs to put oneself in the writer's or actor's shoes and try to understand their situation, concerns, role, concepts, information and perceptions in order (to) reconstruct what they were thinking and what it meant" 24 . In the book, Twining reveals the admiration for Hart's "idea of internal points of view" 25 and highlights the powerful differentiation of standpoint made by Jeremy Bentham between the expositor and the censor, ${ }^{26}$ but also explains his preference for legal realism with the key concepts of "standpoints and multiple perspectives". ${ }^{27}$ Academic law is a participant-oriented discipline, in which participants play different roles and should typically adopt the normative model of a given standard role. ${ }^{28}$ In theorizing standpoint, we may examine how legal actors operate in different contexts with their

\footnotetext{
20 Idem, 362.

${ }^{21}$ Idem, 449-451.

${ }^{22}$ William Twining, Jurist in Context: A Memoir (CUP 2019) 116. History (OUP 1994) 282-302.

24 William Twining, Jurist in Context: A Memoir (CUP 2019) 117.

${ }^{25}$ Idem 118.

${ }^{26}$ Idem 119.

27 Idem 118.

${ }^{28}$ Idem 119-120.
}

${ }^{23}$ According to Collingwood, history is the history of thought and "the historian of a certain thought must think for himself that very same thought, not another like it". R. G. Colingwood, An Autobiography (OUP 1978) 111. He also proposes that historical knowledge should be "the reenactment in the historian's mind of the thought whose history he is studying" and also "the reenactment of a past thought incapsulated in a context of present thoughts which, by contradicting it, confine it to a plane different from theirs". Idem 112 \& 114. See also R. G. Colignwood, The Principles of History and Other Writings in Philosophy of History (OUP 1999) 170-208; R. G. Collingwood, The Idea of 
objectives and resources in a way that reduces the unrealism of legal analysis without eliminating objectivity, once we adopt the standpoint with the necessary relative detachment. $^{29}$

Twining is a well-known legal realist and recently even made a restatement of the theses of legal realism as part of the neo-realist project. ${ }^{30}$ His knowledge of legal realism and of the life and work of Karl Llewellyn, a leading figure of the realist movement, resulted in the monumental book Karl Llewellyn and the Realist Movement. ${ }^{31}$ In the afterword for the second edition, Twining had already revealed that he was an accidental legal realist. Initially he became interested in studying with Lon Fuller, but Harvard responded that they only gave scholarships for degree programs and it was already too late for the following academic year. ${ }^{32}$ Therefore, Twining decided to apply to the University of Chicago and was accepted to become a pupil of Karl Llewellyn there. ${ }^{33}$ In his biography, Twining explains how Karl Llewellyn influenced decisively his reasoning and changed him. First, the professor diagnosed the pupil's condition as of someone suffering from 'Korzybskian paralysis' by finding the new tool of conceptual analysis and being obsessed and over-using it. ${ }^{34}$ Second, Twining had felt despair by the gap between law in the books and law in action and the experience of the English bar exams, and was attracted by Llewellyn's concern with practice, his down-to-earth attitude, and interest in the activity of lawyers. ${ }^{35}$ Third, Twining found rewarding the combination of an emphasis on legal technology, skills and crafts with the central role of ethics, justice and idealism - without a dogmatic stance on values. ${ }^{36}$ Fourth, the more important for Twining was Llewellyn's encouragement towards the development of the 'Weltanschaaung' - that is an independent personal 'whole view' of law in society. ${ }^{37}$ The influence of legal realism became decisive for Twining's teaching and scholarship. Realism also shaped Twining's contributions to the study of globalization of law, as we will see in the next section.

${ }^{29}$ Idem 120-123.

30 William Twining, Legal R/realism and Jurisprudence: Ten Theses in The New Legal Realism in Elisabeth Mertz, Stewart Macaulay and Thomas W. Mitchell (eds), The New Legal Realism: Translating Law-And-Society for Today's Legal Practice (CUP 2016) 121-146.

31 William Twining, Karl Llewellyn and the Realist Movement (CUP 2nd edn 2012).

32 Idem 391.

33 Idem 391.

${ }^{34}$ William Twining, Jurist in Context: A Memoir (CUP 2019) 34-35.

${ }^{35}$ Idem 37.

36 Idem.

${ }^{37}$ Idem 37-38.

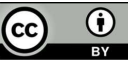




\section{AN ACADEMic GLOBETROTTER AND His StUdy OF GLOBALIZATION OF LAW}

One of the interesting contributions of this memoir to our knowledge of the relationship between Twining's life and his work consists of details of his various travels across the globe. Born in Kampala on 22 September 1934, he spent his first ten years of life in Uganda and then in wartime Mauritius. ${ }^{38}$ During his legal studies, his mind was focused on "literature, politics, and East Africa" 39 and his 'Oxford self' was in tension during his holidays in Dar es Salaam with his parents. ${ }^{40}$ On his twenty-first birthday, he met the Principal of Makerere College, then the only university institution in East Africa, and made a visit that confirmed his interest in African universities and realized that he wanted to teach Law in Africa. ${ }^{41}$ Immediately after marrying Penelope, they moved to Chicago for the academic year of 1957-1958.42 After their year in the U.S., William was appointed lecturer in Private Law at the University of Khartoum between 1958-1961 ${ }^{43}$ and, subsequently, a senior lecturer of the Faculty of Law in University College Dar es Salaam between 1961-1965. ${ }^{44}$ In the meantime, however, Twining contacted Soia Mentschikoff Llewellyn and had access to Karl Llewellyn's papers in Chicago in 1963-1964 after his sudden death. As part of his research on American Legal Realism, he spent additional time at Yale in 1965 and at UPenn in $1971 .{ }^{45}$ In the end, especially because he became a regular Visiting Professor to University of Miami Law School since 1981, Twining estimates having spent one fourth of his working life in the U.S. ${ }^{46}$ Additionally to his experiences in Africa and the U.S., Twining was also a Law Professor in Belfast (1966-1972), Warwick (1972-1982), and UCL (1983-1999). ${ }^{47}$

His experience as a globetrotter helps understanding his worldview of law in society, especially globalization of law. First, Twining is very cautious about the use of the word globalization and other 'g-words' like global and globalized, especially because the literature ignores all intermediate levels and the sub-worlds between the local and the global level. ${ }^{48}$ Human beings, groups and peoples are becoming interdependent

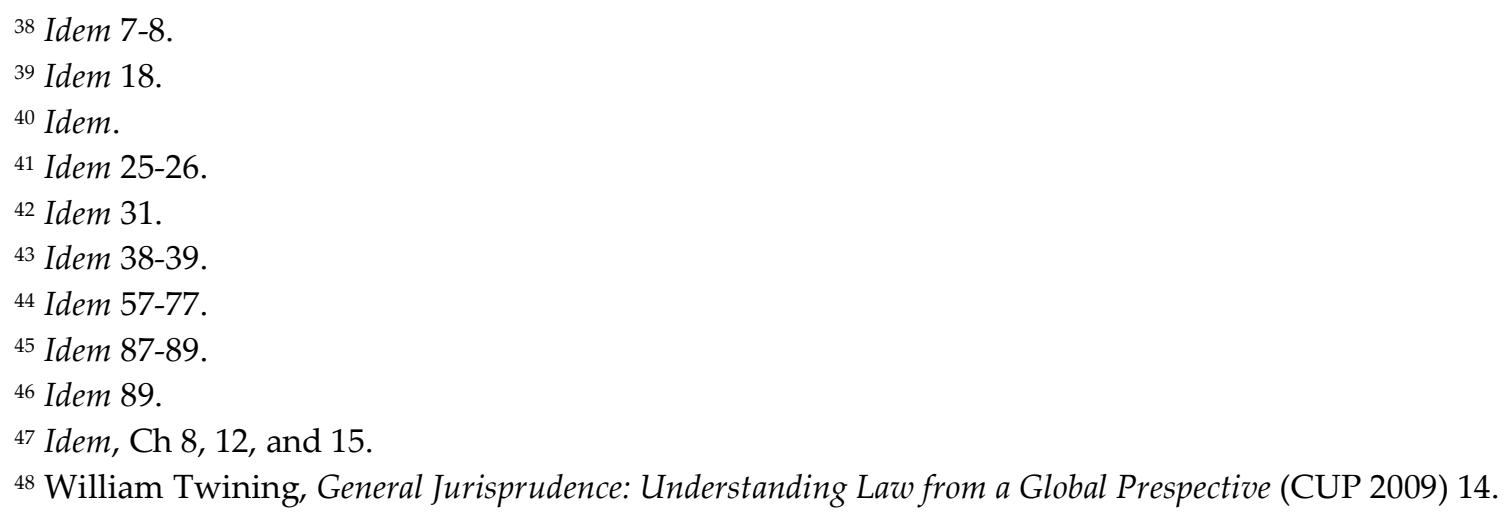


through complex processes at sub-global levels. ${ }^{49}$ Therefore, the transnationalization of law includes the role of empires, alliances, coalitions, diasporas, networks, trade routes, and movements and the legal relations within particular 'sub-worlds' (e.g. the Arab world, the Islamic world, Christendom, etc.) and special groupings of power (e.g. G8, E.U., the Commonwealth, and multi-national corporations, NGOs, etc.)..$^{50}$ Even organizations that claim to be global - like the World Bank, FIFA, and Amnesty International - deal with all levels of relations and ordering and depend on significant regional and local bodies and regimes to pursue their objectives. ${ }^{51}$ Legal analysis requires understanding of boundaries, borders, jurisdictions, treaty relations, and legal traditions and a realistic demographic picture of the scale and distribution of institutions, regimes, and orders across space and time. ${ }^{52}$ Not surprisingly, the central thesis of General Jurisprudence: Understanding Law From a Global Perspective is the call for a more cosmopolitan jurisprudence that "needs to broaden its reach to take more account of non-Western legal traditions, a wider range of legal phenomena, and different levels of normative and legal relations and ordering"..$^{53}$

The careful reading of Jurist in Context: A Memoir reveals a series of encounters with history and demographics that explains this personal view and the demands for rigorous legal analysis and careful examination of globalization of law. The Twinings moved to Sudan only a few years after the country's independence in 1956 and had to navigate a web of complex relationships there. In Khartoum, they experienced their first revolution and an episode of book burning of all copies that were published in Israel as part of the anti-Zionist fever stimulated by the military regime. ${ }^{54}$ In Dar es Salaam, the academic project of establishing a new university and the first faculty was directly related to the self-government and independence of Tanganyika (later Tanzania). ${ }^{55}$ In this political context, there was a lot of concern about the meaning of symbols and whether academic gowns and architecture were ideologically adequate or improper representations of subordination and a colonial past that should be abandoned ${ }^{56}$ In Belfast, there were the Troubles, Bloody Sunday, and a setting of schools segregated by religion, class, and gender. ${ }^{57}$ In Warwick, there was the opportunity to establish a radically different law school and to challenge the status quo

${ }^{49}$ Idem 14-15.

${ }^{50} \mathrm{Idem}$.

${ }^{51}$ Idem 15.

${ }^{52}$ Idem 15-16.

53 Idem 24.

${ }^{54}$ William Twining, Jurist in Context: A Memoir (CUP 2019) 50-51.

${ }^{55}$ Idem 57.

${ }^{56}$ Idem 65-68.

${ }^{57}$ Idem 96-98. 
of the English legal education. ${ }^{58}$ At UCL, Twining could revive the Benthamite ethos through the prestigious Quain Chair of Jurisprudence and challenge the structure of postgraduate research at the University of London that should value more its cosmopolitan ambiance. ${ }^{59}$ It was at UCL that he finally decided to set a research project on globalization and law.

During this period, Twining revived his African interests and adopted his cautious view that the analysis of globalization should not be reduced to economic relations, consequences of capitalism or American hegemonic forces. ${ }^{60} \mathrm{He}$ criticizes the excessive vocabulary of 'globababble' that refers uncritically to 'global law schools', 'global law firms', 'global lawyers', and 'Global Law degrees' and asks whether these actors are involved in teaching, lawyering, and studying law of every legal system of every country? ${ }^{61}$ Again, Twining wishes to confine the use of the g-word, because it often refers to sub-global and transnational phenomena without analytical force. ${ }^{62}$ On the other hand, Twining proposes a mapping exercise that could illustrate "the nearubiquity of normative and legal orders co-existing in the same time-space contexts and a map of legal traditions illustrates how laws, legal traditions and legal devices have interacted through history". ${ }^{63}$ This empirical and interdisciplinary description of globalization in cartography inevitably leads us back to our location in the map and to our standpoint: "Globalization touches everyone, but it affects individuals, institutions, and groups in very many ways". ${ }^{64}$ One should not ask questions in abstract, but rather in concrete and to consider what are the implications of globalization for oneself. ${ }^{65}$ Early in the book, for instance, as part of his childhood recollections, William provides a candid example of this exercise, by stating that his father had a 'good war' and analyzing that the World War II made his career take off and he was very successful. ${ }^{66}$ In summary, globalization is not monolithic, but happens in various ways, degrees, and contexts and demographic realism requires that we take seriously normative pluralism, comparative methods, and analyze diffusion of law in society. ${ }^{67}$ In other words, we should examine law in context and recur to interdisciplinary legal studies, which are the themes of the next section.

\footnotetext{
${ }^{58}$ Idem 148-151.

${ }^{59}$ Idem 190-200.

${ }^{60}$ Idem 231-232.

${ }^{61}$ Idem 234.

62 Idem 234.

${ }^{63}$ Idem 236-237.

${ }^{64}$ Idem 239.

65 Idem 239.

${ }_{66}$ Idem 9.

${ }^{67}$ Idem 243.
} 


\section{LAW IN CONTEXT AND INTERDISCIPLINARY LEGAL STUDIES}

In the preface of the memoir, Twining explains the reader that he is "more of a contextualist than Collingwood, so my story is firmly located in particular times and places". ${ }^{68}$ This is true, but also an understatement. Twining is the quintessential contextualist also as the founding co-editor of the Law in Context Series in 1966 and still today a co-editor. Editing the series is the most satisfactory scholarly activity for Twining, "like being a midwife to over a hundred babies" ${ }^{69}$ Additionally to the book series, the 'law in context' approach marked his time at Warwick Law School, in which legal education focused on real-life social and political problems, emphasized foreign law, and provided legal tools for understanding law in society. ${ }^{70}$ The process of broadening the scope of a legal discipline and turning it into a law in context approach was labeled "Warwickisation" and involved rethinking the theme from a concrete and interdisciplinary perspective. ${ }^{71}$

A prodigious example comes from tort law, whose standard book during Twining's studies in Oxford - Salmond on torts - was simply not useful in real life for practicing lawyers. William had experienced another episode of culture shock while teaching torts in Sudan. While explaining the tort case related to the camel that bits the hand of a child in the London Zoo, Sudanese students were puzzled that a camel was in a zoo. ${ }^{72}$ Twining thought that they were missing the point and then suddenly realized "that the fatalism of Islamic culture embodied in Insha'Allah (God wills it) provided a coherent basis for a law of obligations suited to the Sudan: Insha'Allah - the loss lies where it falls". ${ }^{73}$ Patrick Atiyah was one of his closest colleagues, his neighbor, and his main mentor in Khartoum, playing an important role in his intellectual development. ${ }^{74}$ Invited to participate in the Law in Context Series, Atiyah produced his excellent Accidents, Compensation and the Law, ${ }^{75}$ providing a critical overview of compensation system, dealing with insurance, settlements, and the unpredictability of damages awards. ${ }^{76}$ This highly critical account of the inconsistencies and incoherence of Torts regime framed the doctrinal debate by setting proposals of legal reform that

${ }^{68}$ Idem, XV.

${ }^{69} \mathrm{Idem} 92$.

${ }^{70}$ Idem 150.

${ }^{71} \mathrm{Idem}$.

${ }^{72}$ Idem 46-47.

${ }^{73} \mathrm{Idem} 47$.

${ }^{74}$ Idem 41.

${ }^{75}$ Patrick Atiyah, Accidents, Compensation and the Law (CUP 1970).

${ }^{76}$ William Twining, Jurist in Context: A Memoir (CUP 2019) 154.

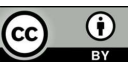

5 JOURNAL OF INSTITUTIONAL STUDIES 2 (2019)

Revista Estudos Institucionais, v. 5, n. 2, p. 777-790, maio/dez. 2019 
were acknowledged and discussed by other authors. ${ }^{77}$ Five decades later the book resisted the test of time and Atiyah's Accidents, Compensation and the Law is already at the ninth edition. ${ }^{78}$ This instant classic guaranteed Atiyah's place in the pantheon of the great scholars of Tort law. ${ }^{79}$

Importantly, the term 'Law in Context' is not a field concept like sociology of law, but it relates to a broader perspective than the mere doctrinal approach. ${ }^{80}$ It challenges the idea of Law as autonomous and of pure forms of legal knowledge, inviting interdisciplinary perspectives even beyond socio-legal studies and empirical research with social scientific methods. ${ }^{81}$ On the other hand, however, it is not an ideology or a political programme, but simply a framework for breaking out from the narrow tradition of doctrinal legal studies. ${ }^{82}$ Moreover, 'law in context' didn't imply rule skepticism or denial of the relevance of doctrine, especially since rules and doctrine are essential to legal knowledge and doctrine and context complement each other. ${ }^{83}$ But the term 'law' in the 'law in context' movement is not restricted to doctrine, but also includes institutions, processes, structures, practices, personnel, and craft traditions. ${ }^{84}$ In Twining's view, "the central message of realism is that doctrine cannot be self-contained, treated in isolation as a thing in itself and for most practical and theoretical purposes the study of doctrine alone is not enough". ${ }^{85}$

In his Hamlyn Lectures titled Blackstone's Tower: The English Law School, ${ }^{86}$ Twining praised the research conducted by the Oxford Centre for Socio-Legal Studies (CSLS) and the spread of socio-legal work in the U.K., welcoming the foundation of the SocioLegal Studies Association (SLSA) in $1990 .{ }^{87}$ However, William was concerned that sociolegal studies was not established as a multi-disciplinary enterprise very far beyond the Oxford Centre and thought that it was at a critical point for either development or decline. ${ }^{88}$ The idea that an English Law School should be examined metaphorically as a Blackstone's Tower evoked the doctrinal tradition, its recent creation and

\footnotetext{
77 Idem 154-155.

78 Peter Cane and James Gouldkamp, Atiyah's Accidents, Compensation and the Law (Cambridge 9 th $^{\text {edn }}$ 2018).

79 See James Goudkamp, Professor Patrick Atiyah (1931-2018), in James Goudkamp and Donal Nolan (eds) Scholars of Tort Law (Hart 2019).

${ }^{80}$ William Twining, Jurist in Context: A Memoir (CUP 2019) 161.

${ }^{81}$ Idem 162-163.

$82 \mathrm{I}$ dem 164.

${ }^{83}$ Idem 168-169.

84 Idem 172-173.

${ }^{85} \mathrm{Idem} 173$.

86 William Twining, Blackstone's Tower: The English Law School (Sweet \& Maxwell 1994).

87 Idem 144-145.

88 Idem 145.
} 
assimilation into the University, and the potential to exclude outsiders. ${ }^{89}$ Challenging the view of the law school as an Ivory Tower, Twining defended that academic enterprise should take a critical view, explore and develop new fields, be involved also in applied research, make useful contributions to legal practice and deal with all aspects related to law. ${ }^{90}$ In his memoir, Twining only referred briefly to his Hamlyn Lectures as the "most scholarly of my writings about legal education", 91 but he doesn't revisit the theme in detail. Yet, he briefly noted that in 2004 a majority of English academic lawyers interviewed by Fiona Cownie claimed to favor law in context and contextual approaches become part of the mainstream. ${ }^{92}$

As an explorer of legal borderlands, Twining reexamines in detail the theme of social and legal rules and focuses on normative pluralism, by highlighting the examples of different rules and norms that one encounters every week. ${ }^{93}$ Twining's list includes tens of examples, such as diet regimes, driving etiquette, parking regulations, IT Protocols and algorithms, Facebook conventions, internal governance of a law school, and several others. ${ }^{94}$ Revisiting the theme of How to Do Things with Rules, ${ }^{95}$ Twining reminds us on the impact of pre-conditions, of rule-making, of changes in social contexts or values, and of special features for the analysis of rules. ${ }^{96}$ An important message of The Case of the Legalistic Child should not be missed though: "sometimes problems are best solved by hugs rather than rules". ${ }^{97}$ This candid passage shows that affection may be functionally equivalent to a ruling in solving a controversy. The reference to affection is also a good transitional point to the next section, as the concluding remarks celebrate Jurist in Context: A Memoir in the context of William Twining's $85^{\text {th }}$ birthday.

\section{CONCLUding Remarks in CONTEXT: A Celebration ANd A REVIEW}

I first met William Twining at CSLS in 2012 at my first week to pursue my DPhil there. William has been a regular research associate at the Oxford Centre and was available for conversation and consultation. In the past seven years, we have had

${ }^{89}$ Idem 190-193.

${ }^{90}$ Idem 198.

91 William Twining, Jurist in Context: A Memoir (CUP 2019) 201.

92 Idem 174.

93 Idem 136.

${ }^{94}$ Idem, 136-137.

${ }^{95}$ William Twining and David Miers, How to Do Things With Rules (CUP $5^{\text {th }}$ edn 2010).

${ }_{96}^{6}$ William Twining, Jurist in Context: A Memoir (CUP 2019) 143.

97 Idem 143.

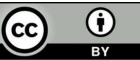


several exchanges and have been involved in a number of projects together in Oxford. ${ }^{98}$ Even if I am just a footnote in his memoir, ${ }^{99}$ his remarkable example of academic and his memorable life will stay with me for the rest of my career. Therefore, one important aspect of this short piece is to celebrate William Twining's life achievements and his $85^{\text {th }}$ birthday, thanking him for being an inspiration for so many people as an explorer of legal borderlands. ${ }^{100}$ In summary, the tone of my text is more celebratory and typical of a festschrift rather than a critical review.

As I mentioned in the introduction, this book is indispensable and excellent. It is another highly original and relevant contribution to the intellectual history of the development of contemporary jurisprudence and will find a place in the bookshelves next to the biography of Karl Llewellyn written also by William Twining and of H.L.A. Hart by Nicola Lacey. But William invited critical feedback, so there is space not only for hugs, but also to follow the rules of a book review. My criticisms are based on the strengths of the other two excellent biographical books of jurists, which are larger and more detailed descriptions of their subjects. In other words, if there is something to criticize in Jurist in Context: A Memoir is that we would like to read more about some points that are missing in the book. For instance, the theme of Law and Development is only covered in two pages and it deserved an independent chapter, as it was an important part of William Twining's professional life not only in Africa, but also as a listed academic interest. We could learn from any biographical reminiscences and

\footnotetext{
98 William was a discussant in the conference on Law and Policy in Latin America that I organized in 2014 and that resulted in an edited collection published a few years later. See Pedro Fortes et alli, Law and Policy in Latin America: Transforming Courts, Institutions, and Rights (Palgrave 2017). As the convener of the Law and Public Affairs Discussion Group, I organized a special session at the Faculty of Law to celebrate the twentieth anniversary of his Hamlyn Lectures Blackstone's Tower: The English Law School in 2014 with Fiona Cownie, Fernanda Pirie, and Andrew Sanders as discussants. See here: https://www.law.ox.ac.uk/events/reflecting-blackstones-tower-and-english-law-school-20-years (checked in 24.09.19). As the editor of the FGV Law School Series, I was delighted to publish his lecture on Law and Literature at one of our issues dedicate to law and popular culture. See William Twining, Direito e Literatura: Sonho de um Diletante? Parte B, em Pedro Fortes (editor), Direito, Cultura Pop e Cultura Clássica (FGV 2015). Not only I attended his lectures during this period, but also had the privilege to have his active participation in discussing my work during my presentations there too. I eventually became also a research associate at CSLS after successfully completing my doctoral degree in 2017 and the opportunity to continue in conversation with William was one of the biggest rewards for extending my affiliation with the Oxford Centre for a period of two years.

${ }^{99}$ I mean it literally. I am just there at Footnote 25 of chapter 9 . It is actually an honor to be remembered and cited. See William Twining, Jurist in Context: A Memoir (CUP 2019) 310-311.

100 As the attentive reader will notice, William Twining's birthday was just in the week before the publication of this review article.
} 
personal frustrations that led him think that the role of law for development is analogous to the role of water for a marriage. ${ }^{101}$

Likewise, he describes his relationships with past and present through Bentham, Dworkin, MacCormick, and Anderson, ${ }^{102}$ but would be great to learn more about his relationships with his own legacy. Perhaps he could have written about the future of legal realism, Law in Context, and interdisciplinary legal studies. ${ }^{103}$ Other passages also deserved further clarification. For instance, referring to the prestigious Quain Chair of Jurisprudence at UCL, he concludes a paragraph with the sentence: "nearly all of my successors have seen the Quain Chair more as a platform than a job"104. Twining moves on to a different topic without detailing exactly what he means. Another example of a sentence that teases the reader and doesn't explain the issue comes at a passage in which he summarizes some contemporary debates in jurisprudence, concluding in a laconic mode that: "This is not the place to revisit these old battles". ${ }^{105}$ Jurisprudential battles attract a lot of interest and William's personal perspective would be really relevant, but limitations of length possibly reduced his capacity to cover these topics in Jurist in Context: A Memoir. Again, we would like to read more and learn more from this extraordinary explorer of legal borderlands.

101 William Twining, Jurist in Context: A Memoir (CUP 2019) 229-231.

102 Idem Ch 16.

103 Perhaps it is unfair to ask William to refer to younger scholars who are already doing a great work as successors, followers, and pupils like Brian Tamanaha, Maksymilian Del Mar, and David Restrepo Amariles, among others. More than just deserving one footnote like myself, these younger scholars are representative of the future of legal realism, the Law in Context Series and interdisciplinary legal studies and it would be really interesting to learn more about William's engagement with them. Therefore, I missed a description of Tamanaha's defense of Twining's work, a comment on Del Mar's role as a co-editor, and an assessment of Amariles' "Mathematical Turn in Law" and his research on legal indicators and algorithmic norms. This missing link with the future is obviously inspired by the vivid description of the troubling relationship that H.L.A. Hart had with Ronald Dworkin so well captured by Nicola Lacey in The Noble Dream and The Nightmare: A Life of H.L.A. Hart. Perhaps the case of William is just too different. Or perhaps it is just expected that the new generations write about the previous ones, just like William himself wrote about Karl Llewellyn and not the other way around. In any event, see, for instance, Brian Tamanaha, A Realistic Theory of Law (CUP 2017) 79; Maksymilian Del Mar and William Twining, Legal Fictions in Theory and Practice (Springer 2015); David Restrepo Amariles, The Mathematical Turn: L'Indicator Rule of Law dans la politique de développement de la Banque Mondiale, in Benoît Frydman et Arnaud Van Waeyenberg (eds), Governeur par les Standards et les Indicateurs: de Hume aux Rankings (Bruylant 2014).

104 William Twining, Jurist in Context: A Memoir (CUP 2019)196.

${ }^{105}$ Idem Page 256. 